\title{
Modulation of antibody secreting cells and neutralizing Ab activity in HIV infected individuals undergoing structured treatment interruptions
}

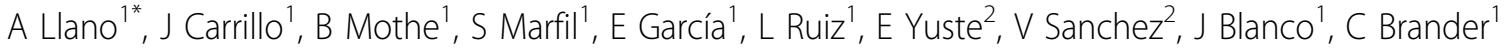 \\ From AIDS Vaccine 2012 \\ Boston, MA, USA. 9-12 September 2012
}

\section{Background}

HIV-1 infection generates numerous abnormalities in the $B$ cell population. The majority of these defects are reverted by antiretroviral therapy. Our aim was to evaluate the effects of re-exposure to HIV antigens on the frequency and functionality of antibody secreting cells (ASC) in patients undergoing structured treatment interruptions (STI). As re-exposure to viral antigens may also boost the production of (neutralizing) antibodies, we also assessed the neutralizing activities during STI cycles.

\section{Methods}

Retrospective study of 10 patients undergoing 3 cycles of STI with 2 weeks on and 4 weeks off HAART. ASC frequencies were determined by flow cytometry in samples obtained at the beginning and the end of STI. Neutralization capacity, total IgG concentration and anti-gp120-IgG titres were evaluated.

\section{Results}

Median viral loads were higher at the end of STI compared to time of treatment stop: 20 [20-1200] vs 615 [20452000] respectively for the first STI, 20[20-654] vs 3655 [20-45900] $(\mathrm{p}<0.05)$ for the second and 35[20-82] vs 290 [20-17400] $(\mathrm{p}<0.05)$ for the third STI. The frequency of ASC followed the same trend: $0.35 \%[0.17-1.15]$ at the beginning of first STI vs $0.27[0.20-4.95]$ at treatment restart, $0.35[0.10-1.40]$ vs $0.82[0.30-3.25]$ for the second and $0.30[0.10-0.70]$ vs $0.40[0.15-1.85]$ for the third STI. Eight out of 10 patients maintained stable total IgG levels during the study. HIV-neutralizing activity was observed in two patients concomitantly with high anti-gp120 titters.

${ }^{1}$ IrsiCaixa AIDS Research Institute, Barcelona, Spain

Full list of author information is available at the end of the article
In one patient the neutralizing activity remained constant while the second patient showed elevated neutralizing $\mathrm{Ab}$ after first STI and once treatment was reinitiated after the 2nd STI.

\section{Conclusion}

Our data suggest that STI and its associated transient increases in viral load drive the frequencies of ASC in an antigen-specific manner. In some subjects, this re-exposure to autologous virus boosts the presence of neutralizing antibodies, albeit in a somewhat delayed manner.

\section{Author details}

${ }^{1}$ IrsiCaixa AIDS Research Institute, Barcelona, Spain. ${ }^{2}$ Institut d'Investigacions Biomediques August Pi i Sunter, Barcelona, Spain.

Published: 13 September 2012

doi:10.1186/1742-4690-9-S2-P63

Cite this article as: Llano et al:: Modulation of antibody secreting cells and neutralizing Ab activity in HIV infected individuals undergoing structured treatment interruptions. Retrovirology 2012 9(Suppl 2):P63.

Submit your next manuscript to BioMed Central and take full advantage of:

- Convenient online submission

- Thorough peer review

- No space constraints or color figure charges

- Immediate publication on acceptance

- Inclusion in PubMed, CAS, Scopus and Google Scholar

- Research which is freely available for redistribution 